\title{
Investigation on the Effect of Emotional Intelligence Training on Self-Esteem Scales of Adolescents Under the Supervision of Behzisti Organization
}

\author{
Atefeh Hooshan ${ }^{1, ~}$, Abolfazl Karami ${ }^{2}$, Farhad Shaghaghi \\ ${ }^{1}$ Department of Psychology, University of Payame Noor, Tehran Branch, Tehran, Iran \\ ${ }^{2}$ Department of Psychology, Faculty of Psychology, University of Alameh Tabatabaei, Tehran, Iran \\ Email address: \\ atefeh1787@yahoo.com (A. Hooshan) \\ *Corresponding author \\ To cite this article: \\ Atefeh Hooshan, Abolfazl Karami, Farhad Shaghaghi. Investigation on the Effect of Emotional Intelligence Training on Self-Esteem Scales \\ of Adolescents Under the Supervision of Behzisti Organization. Psychology and Behavioral Sciences. Vol. 6, No. 6, 2017, pp. 125-134. \\ doi: $10.11648 /$ j.pbs. 20170606.12
}

Received: August 29, 2017; Accepted: November 7, 2017; Published: January 20, 2018

\begin{abstract}
To study the effect of emotional intelligence on self-esteem in adolescents under supervision of Behzisti organization 50 girls living in boarding centers in Tehran were chosen. A total of 25 patients in experimental group and 25 patients were assigned randomly to a control group. Ellis Poop questionnaire was conducted on them. This time round, the questionnaire pretest, post-test and again after training the emotional intelligence to test group was completed by both groups. A third time to determine the lasting effect three months after the further education and training by experimental group were studied. The results show that emotional intelligence education to increase general self-esteem, physical, family, social and decrease the polygraph scores, but changes in educational self-esteem of adolescents under the supervision was not occurred. In the study, lasting effects of emotional intelligence training on self-esteem in Behzisti's adolescents was evident significantly. In total, according to the results it can be stated that teaching emotional intelligence to them can increase their self-esteem in majority of its scales.
\end{abstract}

Keywords: Emotional Intelligence, Self-Esteem, Adolescents, Behzisti Organization, Social Self-Esteem

\section{Introduction}

\subsection{Self-Esteem}

Self-esteem as one of the individual variables is one of the basic human needs, which during the growing process, as a result of internal and external factors affecting individual form and his behavior. The internal factors or factors that comes from within oneself makes it, such as viewpoints, beliefs, actions or behavior and external factors, the environmental factors, verbal and nonverbal messages that are transmitted, experiences makes it a parent, teachers and VIPs in life, organizers and culture [9].

\subsection{Emotional Intelligence}

Many definitions of emotional intelligence has been done is that they all have a kind of supplement other definitions. Goleman defines emotional intelligence is most familiar [10]. He says emotional intelligence is abilities such as being motivated person can use to protect against adversity. In critical condition and impulse can control himself and keep a cool head and does not allow the distress disturb his thinking power compromise, empathy with others and hope. In short, emotional intelligence is a set of attributes that are important in people's fate [1]. The purpose of this research is that emotional intelligence components based on "Bar-on" classification of emotional intelligence is done. His emotional intelligence is divided into five components, each of which encompasses several factors. In this study, each component is selected and trained a number of factors.

\subsection{Bar-on's Emotional Intelligence Theory}

Bar-on and Parker [5] belive that emotional intelligence is the understanding of oneself and others, communicate with 
others, adjustment and adaptation to the environment that it is necessary to know to succeed and meet social demands. These two scientists believe that emotional intelligence and emotional skills, can evolve over time and change its components, and can improve it using training its components and breeding programs such as clinics [4]. Baron [3] created multifactor model for the development of emotional intelligence. $\mathrm{He}$ believed that emotional intelligence functionality consists of one system of skille that his ability to successfully deal with the crisis and confrontations that affect the environment. His emphasis on non-cognitive factors is a typical of the traditional notion of intelligence that reflects the quantity of cognitive factors. In terms of Bar-on factor that emotional intelligence has various dimensions. He introduce fifteen scales which can measure its excitement using the five subscales. Emotional intelligence, social and emotional skills can be improved over time and can be promoted through education and the reform program and treat it. Many factors of emotional intelligence of Bar-on is closely related to the traditional features of a personality. Goleman [10] and Bar-on [3] know the both emotional intelligences as a personality trait. Mayer and Salovey [16] argue that some interpretations of emotional intelligence is misleading because it seems to have paid little attention to the cognitive aspects of this concept. In addition, cognitive abilities, personality traits and mood usually combine [11].

\subsection{The Negative Effects of Living in Boarding Institutions}

Various studies have emphasized the findings that children's emotional style of due to different family communication, is different. In other words, family and educational differences creates the emotional behavior of children. Therefore, if the system suffers from a lack of family communication and problems, consequently children's emotional understanding of the family is in trouble. Research studies conducted in a manner that similar behavior is pathological, suggested that parents of children who have been deprived of their parents or their parents are long patient, in consistent and mental disorders have more problems than normal children [18].

\subsection{Literature Review}

In a study by Sajadi Pour [19] was conducted, "effectiveness of communication skills training program is based on the World Health Organization on adaptation girl students' Behzisti boarding centers in Tehran" was studied and concluded that communication skills training is effective in improving the consistency of students significantly. In another study entitled "The effectiveness of group problem solving skills to increase self-esteem and mental health of adolescent girls under the supervision of boarding centers" by Jahangir [13] was performed, it was found that the method of problem-solving skills training on self-esteem of adolescent girls had influenced and increase it. Khatib Zadeh [14] in a study entitled "The relationship between self-esteem and social development between international and local students of Ilam University" showed that there is a positive relationship between self-esteem and social development. In research of Mostaghimi [17] on the effectiveness of communication skills training on self-esteem 13-15 years' girls living in boarding centers of Tehran's Behzisti, it is found that communication skills training is an effective method to increase the self-esteem of girls of behzisti boarding centers. Blood Worth and et al. [6] have training courses that teach skills such as cooperation, responsibility, empathy, self-control, respect for others, decision making, conflict resolution, good communication with others and increase their self-esteem. The results showed that the performance of education and training courses to improve students' social and emotional problems was very good.

Covington [7] showed that there is a significant relationship between achievement and self-esteem. He remarked that self-esteem can be changed directly through training and similarly on the development of individuals affected and it can be increased. Hatami [12] also examines the components of emotional intelligence education and its impact on self-esteem, self-concept and hardiness of Basij students. The results suggest that interpersonal skills, between people, adaptability, stress management and general mood affects self-concept and hardiness, but components of emotional intelligence training could alter students' selfesteem and only two of them, namely education general mood and interpersonal relationships with self-esteem was not significant relationship. Zare [22] evaluated the relationship between emotional intelligence and academic achievement. In this research he used the Bar-on questionnaire to predict academic success by teaching emotional intelligence, and that there was significant correlation found between Emotional Intelligence and academic achievement. But there is no significant correlation between cognitive intelligence and emotional intelligence. Furnham [8] in a study on 88 people, including 11 males and 77 females, stated that between emotional intelligence, happiness and self-esteem are related. He found that the higher the level of self-esteem, the higher emotional intelligence features such persons; Intrapersonal skills, between people and higher compatibility. In this study, a strong correlation found between interpersonal skills and self-esteem of people relationship management [12].

A study by Sillick and Schutte [21] about the impact of receiving love and affection of parents in childhood on a happy adult showed that people who benefits love and care from their parents at an early age, have higher emotional intelligence. This conclusion on the results Mayer and Solovey [16]. Mayer's research indicates that high emotional intelligence is associated with warmth and intimacy of parents with children. The study also showed that people who have motherly love, fatherly love and minimal emotional intelligence than those that are, are. In other words, motherly love is more useful and effective in enhancing emotional intelligence. The results showed that receives love and happiness to parents increased self-esteem in adulthood has 
an important role (Sillick, 2006 and Schutte, 2006). What this study is trying to do is raise the self-esteem of adolescents under the supervision of Behzisti through education of component of emotional intelligence. Because the low selfesteem, the teenager will make many personal and social problems. This research could have helped to improve the conditions of boarding centers' adolescents, and fixes a lot of problems in these centers and also enhance the power of adaptation, adjustment and increase the success rate of them and a basis for further research in the field of creating better conditions, better and more natural for teens is covered by Behzisti and other boarding centers. The results also can be used in educational centers, research and executive agencies that are doing the work of comforts and services and to open an irresponsible and abandoned children, street children or children who are deprived of a family environment. Among them, Correction and Rehabilitation Center, Social Welfare, Relief Committee and law enforcement. The main objective of this study was to determine the effects of emotional intelligence component training on self-esteem of adolescents under supervision of Behzisti in Tehran.

\subsection{Research Hypothesis}

The hypothesis of this study was to evaluate the effect of training of emotional intelligence components on self-esteem in adolescents under the supervision of the Behzisti include:

1. Training emotional intelligence components increase the general self-esteem of adolescents under the supervision of Behzisiti organization.

2. Training emotional intelligence components increase the educational self-esteem of adolescents under the supervision of Behzisiti organization.

3. Training emotional intelligence components increase the physical self-esteem of adolescents under the supervision of Behzisiti organization.

4. Training emotional intelligence components increase the family self-esteem of adolescents under the supervision of Behzisiti organization.

5. Training emotional intelligence components increase the social self-esteem of adolescents under the supervision of Behzisiti organization.

6. Training emotional intelligence components increase the total self-esteem of adolescents under the supervision of Behzisiti organization.

7. Training emotional intelligence components decrease the polygraphy scores of adolescents under the supervision of Behzisiti organization.

\section{Methods}

This study was performed using a experimental and field research to determine the effect of teaching emotional intelligence factors on the self-esteem of adolescents 16-12 years of Behzisti. To achieve the research objectives and respond to hypotheses, a questionnaire Ellis poop's selfesteem was used. Ellis poop's self-esteem questionnaire in the pre-test which is before the training of emotional intelligence components and post-test one week after the training components, by both the experimental group and the control group was completed. The third stage after 3 months of teaching emotional intelligence factors was just for experimental group was repeated.

\subsection{Statistical Population}

The statistical population of this research consisted of 1612 years old girls living in boarding centers of Behzisti organization and normal girls in the same age group and from the three districts of Tehran.

\subsection{Sample and Sampling Method}

In this study, seven boarding centers in Tehran metropolis: the city of Tehran, Rey and Shemiranat that adolescent girls 16-12 years old kept there were selected. 50 girls aged between 25 patients were randomly assigned to the experimental group and 25 patients in the control group, constitute the research population.

\subsection{Validity and Reliability of the Test}

The validity and reliability of the test in 1991-1992 in Iran in 1056 people by Akbari and Avarzaman is the norm. Akbari and Avarzmani also have used factor analysis confirmed that all the six elements. They used the correlation of every single question with the total score to analyze the question and three question has been deleted.

\subsection{Research Tools}

In the present study, the self-esteem of Behzisti's adolescents, Ellis Poop self-esteem test is used. This test consists of 60 questions and five self-esteem scales used to measure that includes: a general scale, academic, physical, social and family. In addition to these five scales, a scale that is used in lie detector. Each scale has ten questions that will be included in the questionnaire has been distributed. This questionnaire measured general self-esteem scale in general value of his feeling concerned. This feeling affects educational, physical, family and social self-esteem. Educational scale is the individual assessment of the progress and academic ability of their own which is in relation to the expectations that parents, schools and teachers from him. Physical scale is also in relation to the assessment of physical performance of one person from himself. Family scale is the feel and value that person as a member of his family to himself, and also the social scale is the value that person feel connected with others in social interaction. Lie detector scale was used in order to assure the accuracy of test results.

\subsection{Data Collection}

After initially determined randomly assigned to experimental and control groups among them Ellis poop's self-esteem test was completed by teenagers. One week after filling out a questionnaire to the experimental group started a program teaching emotional intelligence factors. A week 
after the meetings, self-esteem questionnaires due to determine the effects of training on self-esteem and emotional intelligence factors in the experimental group compared with the control group was completed again. To determine the lasting effect, three months after the training, the questionnaire was completed for the third time by the groups. Apart from the method of data collection questionnaire was performed by library and archival.

\subsection{The Procedure of Experiment}

After the preliminary steps by visiting the welfare centers in an orientation session with adolescents, necessary explanations and request their cooperation in relation to doing research work was presented. In the after week, the pre-test of self-esteem questionnaires were completed by teens. The components of emotional intelligence according to the Bar-on classification was taught to the experimental group. Bar-on believe that emotional intelligence and emotional health is directly related to each other and it is divided into five components, each of which encompasses several factors. To teach emotional intelligence to this age group of adolescents from each of the five components, several number of factors were considered. From the interpersonal skills: interpersonal factors, empathy and responsibility, from the compatibility: two components of problem solving and flexibility, from the ability to tolerate stress: stress management and impulse control, from general mood: happiness and optimism among the components it have been considered.

The structure of the components of emotional intelligence training sessions comes from the Goleman theory of emotional intelligence and emotional intelligence training methods of Gutmann and has been developed according to the Bar-on classification of components of emotional intelligence training. This program is due to the specific characteristics of adolescents and specific issues that have to communicate with them is a self-made method that has been used to promote emotional intelligence in adolescents. At the end of the third phase of testing, raw scores were extracted and analyzed and compared by computer and SPSS software.

\subsection{Data Analysis Method}

In order to analyze the data, the Kolmogorov-Smirnov test, Levin, T-test, ANOVA, analysis of variance with repeated measures, one-factor experiment with repeated measures, normality correction was used.

\section{Results}

As can be seen in Table 1 pre-test subscales scores of general self-esteem, physical self-esteem and family selfesteem don't have normal distribution $(\mathrm{P}<0.05)$. So if the variance of groups scores in each of these subscales are equal, the correct formula normality (log-score plus one) will be used. But the polygraphy scores, total score and subscale scores of educational self-esteem and social self-esteem of the pre-test have normal distribution $(\mathrm{P}>0.05)$. The scores of total self-esteem and its subscales in post-test have normal distribution. Also polygraphy scores in post-test does not have normal distribution.

Table 1. Kolmogorov-Smirnov test for normality test of scores' distribution.

\begin{tabular}{|c|c|c|c|c|}
\hline & Average & Standard Deviation & Kolmogorov-Smirnov & Significance level \\
\hline \multicolumn{5}{|l|}{ Pre-test } \\
\hline General self-esteem & 10.7 & 2.929 & 1.636 & 0.009 \\
\hline Educational self-esteem & 8.72 & 3.441 & 0.727 & 0.665 \\
\hline Physical self-esteem & 10.88 & 2.932 & 1.9 & 0.001 \\
\hline Family self-esteem & 8.78 & 3.4 & 1.415 & 0.036 \\
\hline Social self-esteem & 10.84 & 2.923 & 0.949 & 0.328 \\
\hline Polygraphy & 10.24 & 1.756 & 1.042 & 0.227 \\
\hline \multicolumn{5}{|l|}{ Post-test } \\
\hline General self-esteem & 12.22 & 2.286 & 0.759 & 0.612 \\
\hline Educational self-esteem & 9.46 & 3.442 & 0.737 & 0.648 \\
\hline Physical self-esteem & 12.08 & 2.842 & 1.216 & 0.104 \\
\hline Family self-esteem & 8.62 & 3.057 & 0.987 & 0.284 \\
\hline Social self-esteem & 12.1 & 3.105 & 1.058 & 0.326 \\
\hline Polygraphy & 9.16 & 1.67 & 1.361 & 0.049 \\
\hline
\end{tabular}

\subsection{First Hypothesis: Training Emotional Intelligence Components Increase the General Self-Esteem of Adolescents Under the Supervision of Behzisiti Organization}

According to the results in Table 1, the mean differences distribution both experiment and control groups is not normal in general self-esteem scale $(\mathrm{P}<0.05)$. Therefore, the corrected normality for these scores is used. According to Table 2 the variance of the two groups are equal $(\mathrm{P}>0.05)$, so that could be one-way ANOVA to determine the differences between the two groups of adolescents. 
Table 2. Levene test for equality of variances test scores of general self-esteem.

\begin{tabular}{lllll}
\hline & F & First degree of freedom & Second degree of freedom & Significance level \\
\hline Pre-test & 0.077 & 1 & 48 & 0.783 \\
Post-test & 0.004 & 1 & 48 & 0.951 \\
\hline
\end{tabular}

Table 3 shows the results of analysis of one-way ANOVA to test scores between subjects in the two groups in general selfesteem scale which showed that the mean scores of the two groups are significantly different, so that the training of emotional intelligence components increased the general self-esteem of adolescent under the supervision of Behzisti, significantly.

Table 3. One-way ANOVA test for significant differences in the mean scores of two groups of adolescents (experimental group vs. control) in general selfesteem.

\begin{tabular}{|c|c|c|c|c|c|c|}
\hline & & Average & $\mathbf{F}$ & $\begin{array}{l}\text { First degree of } \\
\text { freedom }\end{array}$ & $\begin{array}{l}\text { Second degree of } \\
\text { freedom }\end{array}$ & Significance level \\
\hline \multirow{2}{*}{ Experiment } & Pre-test & 10.60 & 19.418 & 1 & 48 & 0.00 \\
\hline & Post-test & 13.44 & $?$ & $?$ & $?$ & $?$ \\
\hline Control & Post-test & 11.00 & $?$ & $?$ & $?$ & $?$ \\
\hline
\end{tabular}

\subsection{Second Hypothesis: Training Emotional Intelligence Components Increase the Educational Self-Esteem of Adolescents Under the Supervision of Behzisiti Organization}

According to the results in Table 1, the mean differences distribution of both experiment and control groups is normal in educational self-esteem scale $(\mathrm{P}>0.05)$. According to Table 4 the variance of the two groups are equal ( $\mathrm{P}>0.05)$, so that could be one-way ANOVA to determine the differences between the two groups of adolescents.

Table 4. Levene test for equality of variances test scores of educational self-esteem.

\begin{tabular}{lllll}
\hline & F & First degree of freedom & Second degree of freedom & Significance level \\
\hline Pre-test & 1.546 & 1 & 48 & 0.220 \\
Post-test & 2.865 & 1 & 48 & 0.097 \\
\hline
\end{tabular}

Table 5 shows the results of analysis of one-way ANOVA to test scores between subjects in the two groups in general selfesteem scale which showed that the mean scores of the two groups are not significantly different, so that the training of emotional intelligence components could not increase the educational self-esteem of adolescent under the supervision of Behzisti, significantly.

Table 5. One-way ANOVA test for significant differences in the mean scores of two groups of adolescents (experimental group vs. control) in educational selfesteem.

\begin{tabular}{|c|c|c|c|c|c|c|}
\hline & & Average & $\mathbf{F}$ & $\begin{array}{l}\text { First degree of } \\
\text { freedom }\end{array}$ & $\begin{array}{l}\text { Second degree of } \\
\text { freedom }\end{array}$ & Significance level \\
\hline \multirow{2}{*}{ Experiment } & Pre-test & 8.60 & 3.026 & 1 & 48 & 0.088 \\
\hline & Post-test & 9.92 & $?$ & $?$ & $?$ & $?$ \\
\hline \multirow{2}{*}{ Control } & Pre-test & 8.84 & $?$ & $?$ & $?$ & $?$ \\
\hline & Post-test & 9.00 & $?$ & $?$ & $?$ & $?$ \\
\hline
\end{tabular}

\subsection{Third Hypothesis: Training Emotional Intelligence Components Increase the Physical Self-Esteem of Adolescents Under the Supervision of Behzisiti Organization}

According to the results in Table 1, the mean differences distribution both experiment and control groups is not normal in physical self-esteem scale $(\mathrm{P}<0.05)$. Therefore, the corrected normality for these scores is used. According to Table 6 the variance of the two groups are equal $(\mathrm{P}>0.05)$, so that could be one-way ANOVA to determine the differences between the two groups of adolescents.

Table 6. Levene test for equality of variances test scores of physical self-esteem.

\begin{tabular}{lllll}
\hline & F & First degree of freedom & Second degree of freedom & Significance level \\
\hline Pre-test & 0.642 & 1 & 48 & 0.427 \\
Post-test & 0.158 & 1 & 48 & 0.693 \\
\hline
\end{tabular}

Table 7 shows the results of analysis of one-way ANOVA to test scores between subjects in the two groups in physical selfesteem scale which showed that the mean scores of the two groups are significantly different, so that the training of emotional intelligence components increased the physical self-esteem of adolescent under the supervision of Behzisti, significantly. 
Table 7. One-way ANOVA test for significant differences in the mean scores of two groups of adolescents (experimental group vs. control) in physical selfesteem.

\begin{tabular}{|c|c|c|c|c|c|c|}
\hline & & Average & $\mathbf{F}$ & $\begin{array}{l}\text { First degree of } \\
\text { freedom }\end{array}$ & $\begin{array}{l}\text { Second degree of } \\
\text { freedom }\end{array}$ & Significance level \\
\hline \multirow{2}{*}{ Experiment } & Pre-test & 10.92 & 13.538 & 1 & 48 & 0.00 \\
\hline & Post-test & 13.00 & $?$ & $?$ & $?$ & $?$ \\
\hline \multirow{2}{*}{ Control } & Pre-test & 10.84 & $?$ & $?$ & $?$ & $?$ \\
\hline & Post-test & 11.16 & $?$ & $?$ & $?$ & $?$ \\
\hline
\end{tabular}

\subsection{Fourth Hypothesis: Training Emotional Intelligence Components Increase the Family Self-Esteem of Adolescents Under the Supervision of Behzisiti Organization}

According to the results in Table 1, the mean differences distribution both experiment and control groups is not normal in family self-esteem scale $(\mathrm{P}<0.05)$. Therefore, the corrected normality for these scores is used. According to Table 8 the variance of the two groups are equal $(\mathrm{P}>0.05)$, so that could be one-way ANOVA to determine the differences between the two groups of adolescents.

Table 8. Levene test for equality of variances test scores of family self-esteem.

\begin{tabular}{lllll}
\hline & F & First degree of freedom & Second degree of freedom & Significance level \\
\hline Pre-test & 0.217 & 1 & 48 & 0.644 \\
Post-test & 1.235 & 1 & 48 & 0.272 \\
\hline
\end{tabular}

Table 9 shows the results of analysis of one-way ANOVA to test scores between subjects in the two groups in family selfesteem scale which showed that the mean scores of the two groups are significantly different, so that the training of emotional intelligence components increased the family self-esteem of adolescent under the supervision of Behzisti, significantly.

Table 9. One-way ANOVA test for significant differences in the mean scores of two groups of adolescents (experimental group vs. control) in family selfesteem.

\begin{tabular}{lllllll}
\hline & & Average & F & $\begin{array}{l}\text { First degree of } \\
\text { freedom }\end{array}$ & $\begin{array}{l}\text { Second degree of } \\
\text { freedom }\end{array}$ & Significance level \\
\hline \multirow{2}{*}{ Experiment } & Pre-test & 8.52 & 5.771 & 1 & 48 & 0.020 \\
\multirow{2}{*}{ Control } & Post-test & 9.20 & $?$ & $?$ & $?$ & $?$ \\
& Pre-test & 9.04 & $?$ & $?$ & $?$ & $?$ \\
\hline
\end{tabular}

\subsection{Fifth Hypothesis: Training Emotional Intelligence Components Increase the Social Self-Esteem of Adolescents Under the Supervision of Behzisiti Organization}

According to the results in Table 1, the mean differences distribution of both experiment and control groups is normal in social self-esteem scale $(\mathrm{P}>0.05)$. Since the variance of the two groups are not equal, so that could be T-student test to determine the differences between the two groups of adolescents. Table 10 shows the results of analysis of T-student test and showed that the mean scores of the two groups are significantly different, so that the training of emotional intelligence components could not increase the social self-esteem of adolescent under the supervision of Behzisti, significantly.

Table 10. T-student test for equality of significant differences in the mean scores of two groups of adolescents (experimental group vs. control) in social selfesteem.

\begin{tabular}{|c|c|c|c|c|c|c|c|}
\hline & & \multicolumn{3}{|c|}{ Levene Test } & \multicolumn{3}{|c|}{ T-Student Test } \\
\hline & & Average & $\mathbf{F}$ & Significance level & $\mathbf{T}$ & Degree of freedom & Significance level \\
\hline \multirow{2}{*}{ Experiment } & Pre-test & 10.68 & 1.785 & 0.188 & -7.301 & 48 & 0.00 \\
\hline & Post-test & 13.88 & $?$ & $?$ & $?$ & & $?$ \\
\hline \multirow{2}{*}{ Control } & Pre-test & 11.00 & $?$ & $?$ & ? & & ? \\
\hline & Post-test & 10.32 & ? & ? & ? & & $?$ \\
\hline
\end{tabular}

\subsection{Sixth Hypothesis: Training Emotional Intelligence Components Increase the Total Self-Esteem of Adolescents Under the Supervision of Behzisiti Organization}

According to the results in Table 1, the mean differences distribution of both experiment and control groups is normal in total self-esteem scale $(\mathrm{P}>0.05)$. According to Table 11 the variance of the two groups are equal $(\mathrm{P}>0.05)$, so that could be oneway ANOVA to determine the differences between the two groups of adolescents. 
Table 11. Levene test for equality of variances test scores of total self-esteem.

\begin{tabular}{lllll}
\hline & F & First degree of freedom & Second degree of freedom & Significance level \\
\hline Pre-test & 2.352 & 1 & 48 & 0.132 \\
Post-test & 0.353 & 1 & 48 & 0.556 \\
\hline
\end{tabular}

Table 12 shows the results of analysis of one-way ANOVA to test scores between subjects in the two groups in total self-esteem scale which showed that the mean scores of the two groups are not significantly different, so that the training of emotional intelligence componenets could not increase the total self-esteem of adolescent under the supervision of Behzisti, significantly.

Table 12. One-way ANOVA test for significant differences in the mean scores of two groups of adolescents (experimental group vs. control) in total self-esteem.

\begin{tabular}{|c|c|c|c|c|c|c|}
\hline & & Average & $\mathbf{F}$ & $\begin{array}{l}\text { First degree of } \\
\text { freedom }\end{array}$ & $\begin{array}{l}\text { Second degree of } \\
\text { freedom }\end{array}$ & Significance level \\
\hline \multirow{2}{*}{ Experiment } & Pre-test & 59.80 & 32.541 & 1 & 48 & 0.00 \\
\hline & Post-test & 60.52 & $?$ & $?$ & $?$ & $?$ \\
\hline \multirow{2}{*}{ Control } & Pre-test & 68.80 & $?$ & $?$ & $?$ & $?$ \\
\hline & Post-test & 59.67 & $?$ & $?$ & $?$ & $?$ \\
\hline
\end{tabular}

\subsection{Seventh Hypothesis: Training Emotional Intelligence Components Decrease the Polygraphy Scores of Adolescents Under the Supervision of Behzisiti Organization}

According to the results in Tsable 1, the mean differences distribution of both experiment and control groups is normal in polygraphy scale $(\mathrm{P}>0.05)$. According to Table 13 the variance of the two groups are equal $(\mathrm{P}>0.05)$, so that could be one-way ANOVA to determine the differences between the two groups of adolescents.

Table 13. Levene test for equality of variances test scores of total self-esteem.

\begin{tabular}{lllll}
\hline & F & First degree of freedom & Second degree of freedom & Significance level \\
\hline Pre-test & 1.333 & 1 & 48 & 0.254 \\
Post-test & 1.920 & 1 & 48 & 0.172 \\
\hline
\end{tabular}

Table 14 shows the results of analysis of one-way ANOVA to test scores between subjects in the two groups in polygraphy scale which showed that the mean scores of the two groups are not significantly different, so that the training of emotional intelligence components could decrease the polygraphy scores of adolescent under the supervision of Behzisti, significantly.

Table 14. One-way ANOVA test for significant differences in the mean scores of two groups of adolescents (experimental group vs. control) in polygraphy scores.

\begin{tabular}{|c|c|c|c|c|c|c|}
\hline & & Average & $\mathbf{F}$ & $\begin{array}{l}\text { First degree of } \\
\text { freedom }\end{array}$ & $\begin{array}{l}\text { Second degree of } \\
\text { freedom }\end{array}$ & Significance level \\
\hline \multirow{2}{*}{ Experiment } & Pre-test & 10.48 & 0.027 & 1 & 48 & 0.871 \\
\hline & Post-test & 9.36 & $?$ & $?$ & $?$ & $?$ \\
\hline \multirow{2}{*}{ Control } & Pre-test & 10.00 & $?$ & $?$ & $?$ & $?$ \\
\hline & Post-test & 8.96 & $?$ & $?$ & $?$ & $?$ \\
\hline
\end{tabular}

\subsection{Hypotheses Related to the Effect of Emotional Intelligence and Its Survival in the Experimental Group Under the Supervision of Behzisti}

In this section to test the hypotheses that are discussed in connection with the follow-up study, the survival effects of training on increasing self-esteem and overall emotional intelligence and its subscales in the experimental group to be determined. Since the scores of physical subscales, family and general self-esteem in pre-test is not normal, corrected normality for all score of pre-test, post-test, and follow-up in these three sub-scales were used. In this section the one-factor experiment with repeated measures was used.

\section{Discussion}

In Table 15 the mean, standard deviation and analysis of variance with repeated measures factor for scores of pre-test, posttest and follow-up of general self-esteem's subscales are presented:

Table 15. Repeated measures analysis of one-factor test for significant differences in the mean scores of pre-test, post-test and follow-up of general self-esteem.

\begin{tabular}{|c|c|c|c|c|c|c|c|}
\hline & Average & Standard deviation & & $\mathbf{F}$ & First degree of freedom & $\begin{array}{l}\text { Second degree of } \\
\text { freedom }\end{array}$ & Significance level \\
\hline Pre-test & 10.7 & 2.99 & Within groups & 26.948 & 1 & 24 & 0.000 \\
\hline Post-test & 12.22 & 2.682 & Between groups & 669.577 & & & 0.000 \\
\hline Follow-up & 13.52 & 3.242 & & & & & \\
\hline
\end{tabular}


Before the test, scores were corrected for normality. As reflected in the table, the differences between the three measurements is significant. In Table 16 the mean, standard deviation and analysis of variance with repeated measures factor for scores of pre-test, post-test and follow-up of educational self-esteem's subscales are presented:

Table 16. Repeated measures analysis of one-factor test for significant differences in the mean scores of pre-test, post-test and follow-up of educational selfesteem.

\begin{tabular}{|c|c|c|c|c|c|c|c|}
\hline & Average & $\begin{array}{l}\text { Standard } \\
\text { deviation }\end{array}$ & & $\mathbf{F}$ & $\begin{array}{l}\text { First degree of } \\
\text { freedom }\end{array}$ & $\begin{array}{l}\text { Second degree } \\
\text { of freedom }\end{array}$ & $\begin{array}{l}\text { Significance } \\
\text { level }\end{array}$ \\
\hline Pre-test & 8.72 & 3.441 & Within groups & 21.377 & 1 & 24 & 0.000 \\
\hline Post-test & 9.46 & 3.442 & Between groups & 372.321 & & & 0.000 \\
\hline Follow-up & 11.12 & 2.818 & & & & & \\
\hline
\end{tabular}

As reflected in the table, the differences between the three measurements is significant. In Table 17 the mean, standard deviation and analysis of variance with repeated measures factor for scores of pre-test, post-test and follow-up of physical selfesteem's subscales are presented:

Table 17. Repeated measures analysis of one-factor test for significant differences in the mean scores of pre-test, post-test and follow-up of physical selfesteem.

\begin{tabular}{|c|c|c|c|c|c|c|c|}
\hline & Average & $\begin{array}{l}\text { Standard } \\
\text { deviation }\end{array}$ & & $\mathbf{F}$ & $\begin{array}{l}\text { First degree of } \\
\text { freedom }\end{array}$ & $\begin{array}{l}\text { Second degree } \\
\text { of freedom }\end{array}$ & $\begin{array}{l}\text { Significance } \\
\text { level }\end{array}$ \\
\hline Pre-test & 10.88 & 2.932 & Within groups & 40.11 & 1 & 24 & 0.000 \\
\hline Post-test & 12.08 & 2.842 & Between groups & 578.432 & & & 0.000 \\
\hline Follow-up & 13.60 & 3.149 & & & & & \\
\hline
\end{tabular}

Before the test, scores were corrected for normality. As reflected in the table, the differences between the three measurements is significant. In Table 18 the mean, standard deviation and analysis of variance with repeated measures factor for scores of pre-test, post-test and follow-up of social self-esteem's subscales are presented:

Table 18. Repeated measures analysis of one-factor test for significant differences in the mean scores of pre-test, post-test and follow-up of social self-esteem.

\begin{tabular}{|c|c|c|c|c|c|c|c|}
\hline & Average & $\begin{array}{l}\text { Standard } \\
\text { deviation }\end{array}$ & & $\mathbf{F}$ & $\begin{array}{l}\text { First degree of } \\
\text { freedom }\end{array}$ & $\begin{array}{l}\text { Second degree } \\
\text { of freedom }\end{array}$ & $\begin{array}{l}\text { Significance } \\
\text { level }\end{array}$ \\
\hline Pre-test & 10.84 & 2.923 & Within groups & 24.983 & 1 & 24 & 0.000 \\
\hline Post-test & 12.10 & 3.105 & Between groups & 1113.197 & & & 0.000 \\
\hline Follow-up & 13.04 & 2.475 & & & & & \\
\hline
\end{tabular}

Before the test, scores were corrected for normality. As reflected in the table, the differences between the three measurements is significant. In Table 19 the mean, standard deviation and analysis of variance with repeated measures factor for scores of pre-test, post-test and follow-up of family self-esteem's subscales are presented:

Table 19. Repeated measures analysis of one-factor test for significant differences in the mean scores of pre-test, post-test and follow-up of family self-esteem.

\begin{tabular}{|c|c|c|c|c|c|c|c|}
\hline & Average & $\begin{array}{l}\text { Standard } \\
\text { deviation }\end{array}$ & & $\mathbf{F}$ & $\begin{array}{l}\text { First degree of } \\
\text { freedom }\end{array}$ & $\begin{array}{l}\text { Second degree } \\
\text { of freedom }\end{array}$ & $\begin{array}{l}\text { Significance } \\
\text { level }\end{array}$ \\
\hline Pre-test & 8.78 & 3.400 & Within groups & 9.521 & 1 & 24 & 0.005 \\
\hline Post-test & 8.62 & 3.057 & Between groups & 271.605 & & & 0 \\
\hline Follow-up & 10.36 & 3.213 & & & & & \\
\hline
\end{tabular}

Before the test, scores were corrected for normality. As reflected in the table, the differences between the three measurements is significant. In Table 20 the mean, standard deviation and analysis of variance with repeated measures factor for scores of pre-test, post-test and follow-up of total self-esteem's subscales are presented:

Table 20. Repeated measures analysis of one-factor test for significant differences in the mean scores of pre-test, post-test and follow-up of total self-esteem.

\begin{tabular}{|c|c|c|c|c|c|c|c|}
\hline & Average & $\begin{array}{l}\text { Standard } \\
\text { deviation }\end{array}$ & & $\mathbf{F}$ & $\begin{array}{l}\text { First degree of } \\
\text { freedom }\end{array}$ & $\begin{array}{l}\text { Second degree } \\
\text { of freedom }\end{array}$ & $\begin{array}{l}\text { Significance } \\
\text { level }\end{array}$ \\
\hline Pre-test & 60.16 & 13.083 & Within groups & 40.360 & 1 & 24 & 0.000 \\
\hline Post-test & 64.33 & 11.430 & Between groups & 1171.363 & & & 0.000 \\
\hline Follow-up & 71.20 & 11.644 & & & & & \\
\hline
\end{tabular}

Before the test, scores were corrected for normality. As reflected in the table, the differences between the three measurements is significant. According to Figure 1 can be seen in follow-up study, the increased self-esteem scores have been preserved. 


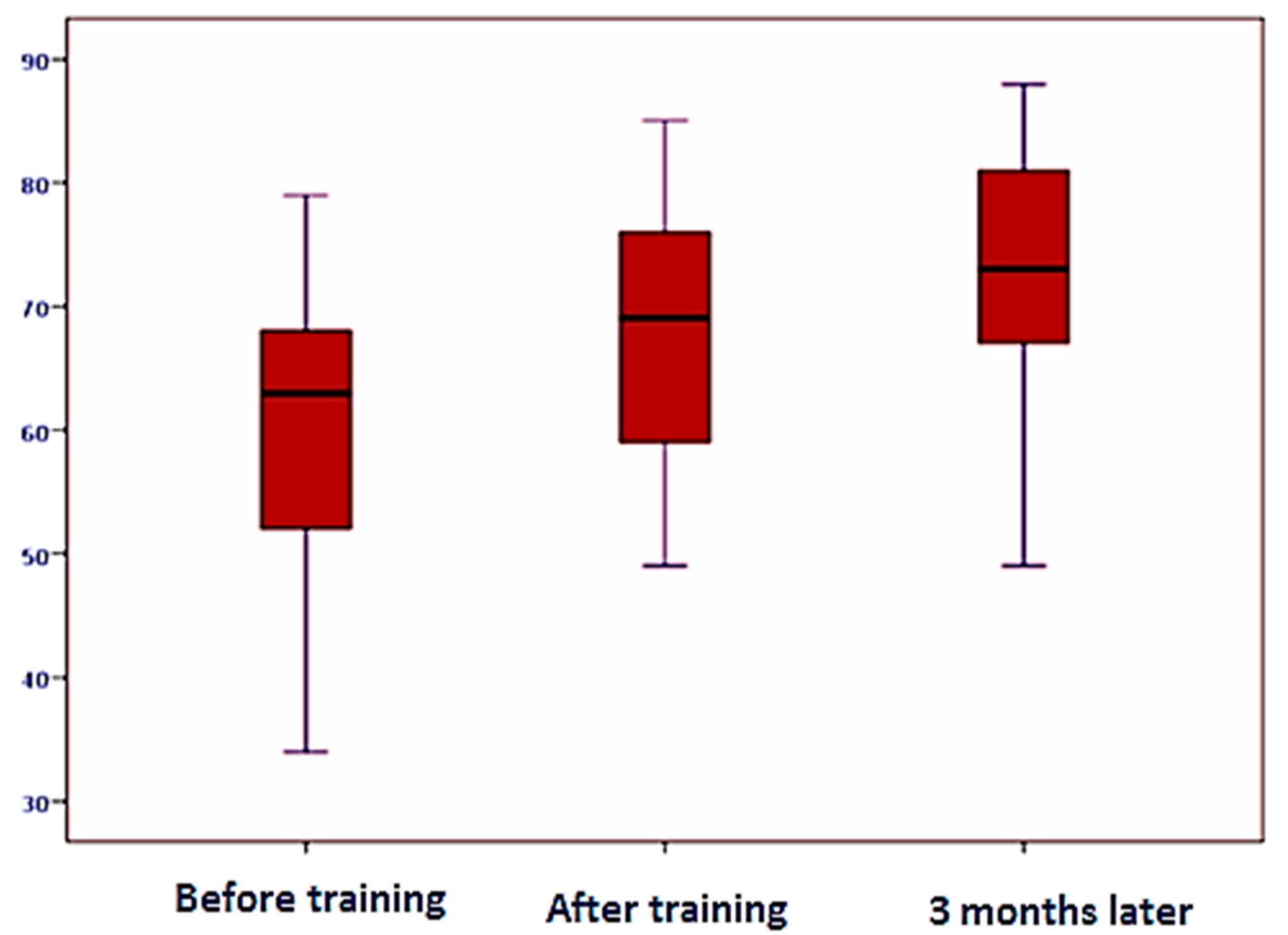

Figure 1. Comparison of total self-esteem before, after and three months after training components of emotional intelligence in the adolescents experimental group under the supervision of Behzisti.

In Table 21 the mean, standard deviation and analysis of variance with repeated measures factor for scores of pre-test, posttest and follow-up of polygraphy's subscales are presented:

Table 21. Repeated measures analysis of one-factor test for significant differences in the mean scores of pre-test, post-test and follow-up of polygraphy's subscale.

\begin{tabular}{|c|c|c|c|c|c|c|c|}
\hline & Average & $\begin{array}{l}\text { Standard } \\
\text { deviation }\end{array}$ & & $\mathbf{F}$ & $\begin{array}{l}\text { First degree of } \\
\text { freedom }\end{array}$ & $\begin{array}{l}\text { Second degree } \\
\text { of freedom }\end{array}$ & $\begin{array}{l}\text { Significance } \\
\text { level }\end{array}$ \\
\hline Pre-test & 10.24 & 1.756 & Within groups & 4.168 & 1 & 24 & 0.05 \\
\hline Post-test & 9.16 & 1.670 & Between groups & 1432.641 & & & 0.000 \\
\hline Follow-up & 9.56 & 1.502 & & & & & \\
\hline
\end{tabular}

Before the test, scores were corrected for normality. As reflected in the table, the differences between the three measurements is significant.

\section{Conclusions}

To test hypotheses about teaching emotional intelligence and its effect on increasing self-esteem and its subscales for adolescents under the supervision of Behzisti organization, The teenagers are divided into two experimental and control group and the experimental group was trained in emotional intelligence. After completing the training, the self-esteem of adolescents between experimental and control groups were calculated using research tools. The results reveal a significant increase in average of total self-esteem and its subscales in adolescents experimental group compared to the control group which was similar to the findings of Schutte [20]. Many studies have shown that high emotional intelligence with better mental health [2] and higher self- esteem (Schutte, 2006) is associated. In a study of adults who had high emotional intelligence, they said that they had warmth and intimacy of their parents in childhood [15]. In the study of Hatami [12] training components of emotional intelligence, did not change self-esteem of subjects and only two of them: the learning skills of general mood and interpersonal relationships, had significant relationship with their self-esteem. The above mentioned studies the relationship between self-esteem and emotional intelligence and training emotional intelligence components show impact on the self-esteem which are coordinated with the results of this study. In the results of this study raise self-esteem scores on all subscales except educational self-esteem were observed. Given that the study was conducted in the summer and school holidays it can be justified. This is despite the fact that the study of Zare [22] there was a significant correlation between emotional intelligence and academic success. Therefore, the results indicate a significant relationship between emotional intelligence and self-esteem in 
adolescents was under the supervision of Behzisti. To evaluate the durability of the components of emotional intelligence training effect in the self-esteem of adolescents, three months after training the experimental group were tested again with research tools. The findings indicate a significant difference between the average of total selfesteem and general subscales before, after and three months after training the experimental group. This result indicates the effectiveness of emotional intelligence in the teenagers to enhance their self-esteem. According to our findings and note that the emotional intelligence can be taught, therefore by teaching emotional intelligence, both non-obained emotional intelligence of parents in children and adolescents of Behzisti can be increased and raise their self-esteem, so that could partly be compensated for their weaknesses and deficiencies and provide conditions for their success in various fields of life. The results of this study show that the education components of emotional intelligence increased the scores for teenagers under the supervision of Behzisti in the scales of the general, physical, family, social total self-esteem, significantly. But the educational scale because of the emotional intelligence training was peformed in the summer when school was closed, the necessary and sufficient opportunity to evaluate the effect of education on self-esteem did not exist, so no change observed. Thus this emotional intelligence training in total has been effective in increasing self-esteem of adolescents. It is hoped that the study and application of its results can help to improve the self-esteem of the young people. Because the role of self-esteem and success in all aspects of life repeatedly confirmed by several studies. Finally, based on the results can be stated that adolescents under the supervision of Behzisti organization for a better life, feel more valuable and healthy mind, requires adaptability and cost-effective method of improving the quality of their lives.

\section{References}

[1] Aghayar, Siroos and Sharifi Daramadi, Parviz (2006). Emotional intelligence and its application in the territory of excitement. Sepahan Publication. Isfahan.

[2] Austin, E, J., Saklofske, D. H., \& Egan, v. (2005). Personality, well-being, and healt correlates of trait emotional intelligence. Personality and Individul Differences. 38 (3): 547-558.

[3] Bar-on, R. (1997). The Emotion Intelligence Inventory (EQI): Technical manual, Toronto, Canada: multi-health system, Inc.

[4] Bar-on, R. (1999). The Emotion Quotient Inventory (EQ-I): A Test of Emotional Intelligence, Toronto, Canada: multi: health system.

[5] Bar-on, R. and Parker, J. D. A. (2000). Introduction. In Baron, \& J. D. A. Parker (Eds.). The handbook of Emotion Intelligence. Jossey-Bass. San Francisco.

[6] Bloosworth. M. R., Zhks. A. E., Wissberg, H. J. and Walberg,
H. J. (2001). Implication of social and emotional research for education. Evidence liking social skills and academic out comes. Theceic Review.

[7] Covington, M. (1989). Self esteem and failure in school, the social of self-steem. U. C. press, Berkeley. C. A.

[8] Furnham, A. and Cheng, H. (2000). Percieved paternal behavior, self- esteem, andhappiness. Social Psychology and Psychiatric Epidomiology. 35: 463-470.

[9] Gharchedaghi, Mahdi (2000). Psychology of Self-Esteem. Translated to Persian. Nakhostin Publication. Tehran.

[10] Goleman, D. (1995). Emotional Intelligence. Bantam Books. New York.

[11] Hajloo, Mahnaz (2004). The relationship between emotional intelligence and way of coping with stress in managers of schools of Tehran. Master's thesis, Islamic Azad University, Roodehen.

[12] Hatami, Mohamad Reza (2006). Study the effects of training on self-esteem, emotional intelligence, self-awareness, and hardiness of Basij students. PhD thesis, University of Allameh, Faculty of Education and psychology.

[13] Jahangir, Pantea (2004). Evaluation of the effectiveness of group problem solving skills to increase self-esteem and mental health of adolescents under the supervision of boarding senters of Behzisti. Master's thesis, Islamic Azad University, Science and Research Branch.

[14] Khatib Zadeh, Nahid. Examine the relationship between selfesteem and social development among local and international students of Islamic Azad University of Ilam. Master's thesis, Islamic Azad University Science and Research Branch.

[15] Mayer, j, D., Caruso, D. R., and Salovey, P. (1999). Emotional intelligence meets traditional standards for an intelligence. Intelligence. 27 (4): 267-298.

[16] Mayer, J. D., and Solovey, P. (1997). What is emotional intelligence? Inp. Salovey \& D. J. Shuyter (Eds.), Emotional development and emotional Intelligence: Educational implication. Basic Books. New York.

[17] Mostaghimi, Maryam (2008). The effectiveness of communication skills training on self-esteem of girls 13-15 years old living in boarding centers of Tehran. Master's thesis, University of Allameh Tabatabaei.

[18] Pitts, M. and Phillips, K. (1998). The psychology of Hearth. London Routledge.

[19] Sajadi Pour, Farideh Sadat (2007). Effective communication skills training program based on the World Health Organization adaptation girl students' boarding centers in Tehran. Master's thesis, Allameh Tabatabaei University.

[20] Schutte s. Nicola. (2006). School of Psychology, University of New England. Armidal, NSW.

[21] Sillick j. Tamara. (2006). School of Psychology, University of New Englad, 2351 E-journal of applied psychology Emotional Inteligence. Armidal, NSW.

[22] Zare, Mohsen (2001). The study of emotional intelligence in educational achievement. Master's thesis, Tehran Psychiatric Institute. 